Journal of Environmental Science and Public Health

doi: $10.26502 /$ jesph.96120037

Volume 2, Issue 4

Review Article

\title{
Introduction of Human Health associated with Risk Assessment
}

\author{
Sylvia Adipah*
}

Department of Environmental Engineering and Science, Chongqing University, Chongqing, China

"Corresponding Author: Sylvia Adipah, Department of Environmental Engineering and Science, Chongqing University, Chongqing 400044, China

Received: 30 October 2018; Accepted: 08 November 2018; Published: 16 November 2018

\begin{abstract}
The study of this paper is to understand health effects associated with food, water and air. Large number of people faces certain dangers leading to environmental risk. Risk assessment must be put in place to deal with risk-health related issues. Policy makers must have evidence-based practice by identifying risk factors for disease as well as preventive measures. Determination of human exposure to environmental pollutants in water, air, or food has occurred which plays a significant role in human development and health.
\end{abstract}

Keywords: Risk assessment; Food; Water; Air; Health

\section{Introduction}

Risk assessment is a tool that policy makers use to overcome the increased of health related problems such as people exposed to different amounts of toxic substances. Environmental risks have been changed overtime. A risk assessment provides information to policy makers, regulatory agencies, and other risk managers and to the public so that the most appropriate decisions can be made. Risk assessment is defining as human exposure to environmental hazards causing a potential treat to adverse health effects while risk management evaluate, control hazards and reduce environmental impact to create efficiency. For risk to pose threat to human health there must be a source of contamination where chemicals must be released from the source. Chemicals are transported to a receptor of concern such as humans. During the transport, there may be transformation that can change the form or speciation of the chemical, which in turn may make the chemical more or less mobile or toxic. If the chemical is able to contact a sensitive area of a receptor, that is if exposure occurs, there could be a negative impact. 
Risk assessment creates an important value that provides consistent and it helps to indicate the time frame involved, and who or what is affected. It helps identify strategies and priorities such as where in the process risk management decisions can be most effective. It also helps educate all involved factors, exposures, effects, and relative risks that exist at a site or for a particular situation. Risk assessments involve correction action and decision making that is being applied at specific sites to protect human health. The use of risk assessment can be used to make perspective environmental decisions. Toxic substances from air come from natural sources as poisonous substances or manmade sources that can harm the environment or health. These toxic substances are sometimes inhaled causing health problems.

Risk assessment helps scientist to evaluate risks associated with toxic pollutants and helps the government to set regulatory policies to govern the causes and effects of this toxic pollutants. Public health agencies evaluate risk assessment to determine risk associated with risk exposure. Risk assessment is in four categories (1) hazard exposure, (2) exposure assessment, (3) dose-response assessment, and (4) risk characterization. Hazard Exposure: Human health hazard is a substance, activity or condition that is known to have the potential to cause acute or chronic illness if exposure to a substance or condition to endanger life, generate or spread infectious diseases which can affect the health of humans. Exposure to stressor can cause an increase in the incidence of specific health effects. Exposure assessment is the process of measuring the duration of human exposure of an agent to the environment. Exposure can be measured using concentrations in the environment, models of chemical transport and human intake overtime. Dose-response assessment is the severity of adverse health effects related to the amount and condition of exposure to an agent. Risk characterization is the risk assessor's judgment as to the nature and presence or absence of risks, or how information is assessed and how decisions are made to assess human health risk assessment. The following example may help put the use of the risk assessment process for environmental decision making into perspective. A simplistic risk assessment paradigm is shown in Figure 1.

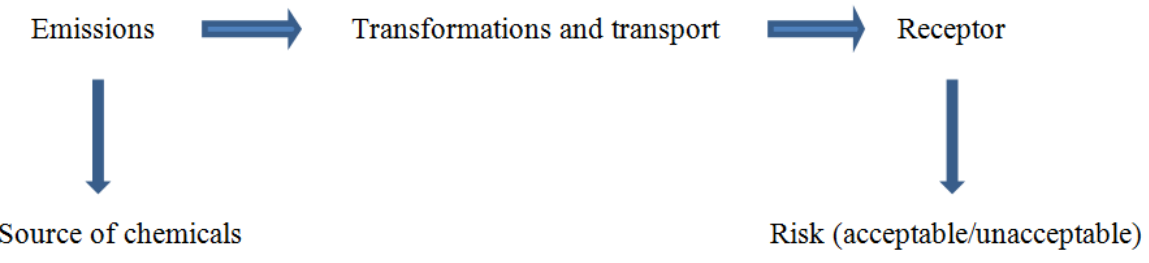

Figure 1: Conceptual risk assessment paradigm. 


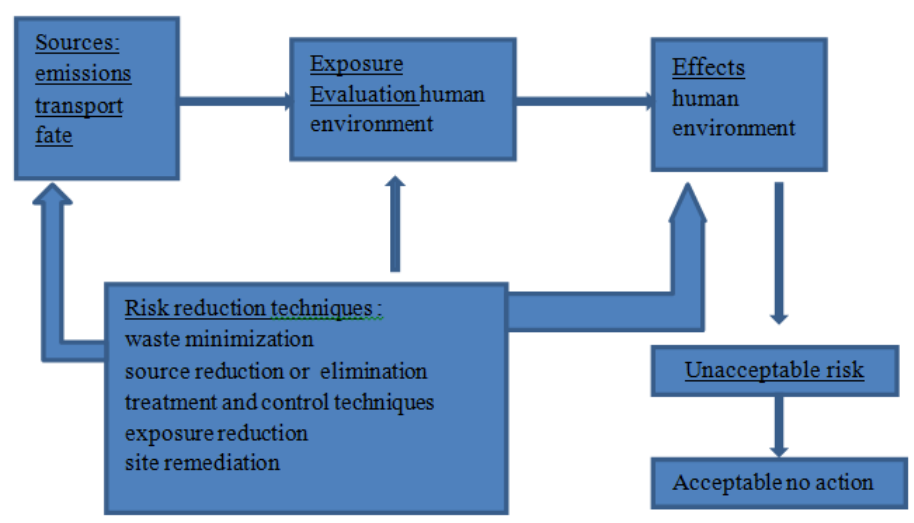

Figure 2: Illustrative engineering risk management approaches.

\section{Food Related Health Risks}

Humans are chemically exposed through food, which is a chemically complex to the environment. Risk assessment can help humans to have sufficient knowledge about recommended intake of some nutrients that is essential for life. Nutrients in food enable the cells in our bodies to perform well and help in growth, development and maintenance of body functions. Saturated fat intake can cause major essential energy, and abusive intakes may be insignificant for some nutrient. Children Food insecurity has been associated with health problems for humans that may hinder their ability to function normally in school or work. Food insecurities can cause hospitalization, chronic health disease and social interactions; it can also cause bad behavior activities in human. Policymakers and stakeholders have to ensure that there is access to food, education and resources to improve food insecurity among humans. Inadequate nutrition can lead to a weakened immune system. Vitamins A, B vitamins and zinc can help build a strong immune system. Well balanced diet must take to meet nutritional needs. The food we take into our bodies can make us overweight, undernourished, and the risk to develop diseases such as heart disease or diabetes because our diet lacks the necessary balance of nutrients. Food produced through agricultural technology can induce an allergic response to some humans.

\begin{tabular}{|l|l|l|l|l|}
\hline Class & Description & $\begin{array}{l}\text { Methods used to Study } \\
\text { Risks and Benefits }\end{array}$ & $\begin{array}{l}\text { Importance and } \\
\text { Source of Health } \\
\text { Risks }\end{array}$ & $\begin{array}{l}\text { Known and } \\
\text { Possible Health } \\
\text { Benefits }\end{array}$ \\
\hline Nutrients & $\begin{array}{l}\text { Macronutrients } \\
\text { (Supply energy) } \\
\text { and micro } \\
\text { nutrients. }\end{array}$ & $\begin{array}{l}\text { Clinical/epidemiological. } \\
\text { Major challenge to develop } \\
\text { experimental models to study } \\
\text { excessive intakes. }\end{array}$ & $\begin{array}{l}\text { Major Excessive } \\
\text { energy, saturated } \\
\text { fat intake; abusive } \\
\text { intakes may be } \\
\text { significant for some } \\
\text { micronutrients. }\end{array}$ & $\begin{array}{l}\text { Major Essential } \\
\text { for life. Levels in } \\
\text { excess of } \\
\text { recommended } \\
\text { intake levels may } \\
\text { prove to be } \\
\text { beneficial. }\end{array}$ \\
\hline
\end{tabular}




\begin{tabular}{|c|c|c|c|c|}
\hline $\begin{array}{l}\text { Natural, non- } \\
\text { nutritive } \\
\text { constituents }\end{array}$ & $\begin{array}{l}\text { Largest and } \\
\text { chemically most } \\
\text { diverse class }\end{array}$ & $\begin{array}{l}\text { Little systematic study, } \\
\text { mostly experimental. }\end{array}$ & $\begin{array}{l}\text { Insufficient } \\
\text { knowledge. A } \\
\text { reasonable } \\
\text { conjecture is that } \\
\text { they are at least } \\
\text { moderately } \\
\text { important. }\end{array}$ & $\begin{array}{l}\text { Insufficient } \\
\text { knowledge. Some } \\
\text { appear to offer } \\
\text { benefits, and } \\
\text { many may prove } \\
\text { to be beneficial. }\end{array}$ \\
\hline $\begin{array}{l}\text { Intentionally } \\
\text { induced } \\
\text { substances, direct } \\
\text { and indirect }\end{array}$ & $\begin{array}{l}\text { Food additives, } \\
\text { GRAS substances. } \\
\text { Pesticides, } \\
\text { veterinary drugs, } \\
\text { feed additives. }\end{array}$ & $\begin{array}{l}\text { Experimental study well } \\
\text { developed. Little } \\
\text { epidemiological study. }\end{array}$ & $\begin{array}{l}\text { Minor/moderate } \\
\text { Many substances } \\
\text { introduced decades } \\
\text { ago, have not been } \\
\text { studied using } \\
\text { current } \\
\text { experimental } \\
\text { methods. } \\
\text { Cumulative effects } \\
\text { unknown. }\end{array}$ & $\begin{array}{l}\text { Minor Some may } \\
\text { provide benefits } \\
\text { through } \\
\text { pathogens } \\
\text { reduction, } \\
\text { preservation of } \\
\text { foods. }\end{array}$ \\
\hline $\begin{array}{l}\text { Chemically } \\
\text { produced during } \\
\text { processing, } \\
\text { preparation }\end{array}$ & $\begin{array}{l}\text { Reaction products } \\
\text { from heating, } \\
\text { irradiation, etc. } \\
\text { Chemically very } \\
\text { diverse. }\end{array}$ & $\begin{array}{l}\text { Little systematic study, } \\
\text { mostly experimental. }\end{array}$ & $\begin{array}{l}\text { Insufficient } \\
\text { knowledge A } \\
\text { reasonable } \\
\text { conjecture is that } \\
\text { they are of minor } \\
\text { but not negligible } \\
\text { importance. }\end{array}$ & $\begin{array}{l}\text { Insufficient } \\
\text { knowledge Not } \\
\text { expected to } \\
\text { confer significant } \\
\text { benefits }\end{array}$ \\
\hline Contaminants & $\begin{array}{l}\text { Substances } \\
\text { permitted under } \\
\text { law to be sold as } \\
\text { supplements. }\end{array}$ & $\begin{array}{l}\text { Several contaminants very } \\
\text { well studied, many not. } \\
\text { Epidemiological } \\
\text { experimental. }\end{array}$ & $\begin{array}{l}\text { Moderate } \\
\text { Pathogens produce } \\
\text { largest number of } \\
\text { countable cases of } \\
\text { food-related illness; } \\
\text { most not serious or } \\
\text { irreversible. } \\
\text { Persistent, bio } \\
\text { accumulative } \\
\text { chemicals are or } \\
\text { concern. }\end{array}$ & $\begin{array}{l}\text { Insufficient } \\
\text { knowledge. Not } \\
\text { expected to } \\
\text { confer benefits. }\end{array}$ \\
\hline $\begin{array}{l}\text { Dietary } \\
\text { supplements }\end{array}$ & $\begin{array}{l}\text { Substance } \\
\text { permitted under }\end{array}$ & $\begin{array}{l}\text { Little systematic study. } \\
\text { Epidemiological/clinical, }\end{array}$ & $\begin{array}{l}\text { Insufficient } \\
\text { knowledge. }\end{array}$ & $\begin{array}{l}\text { Insufficient } \\
\text { knowledge Many }\end{array}$ \\
\hline
\end{tabular}




\begin{tabular}{|l|l|l|l|l|}
\hline & $\begin{array}{l}\text { law to be sold as } \\
\text { supplements }\end{array}$ & experimental all applicable. & $\begin{array}{l}\text { Reasonable } \\
\text { conjecture not } \\
\text { possible. Little } \\
\text { systematic study. }\end{array}$ & $\begin{array}{l}\text { perceived as } \\
\text { beneficial. Little } \\
\text { systematic study, } \\
\text { but increasing. }\end{array}$ \\
\hline $\begin{array}{l}\text { Alcoholic } \\
\text { beverages }\end{array}$ & $\begin{array}{l}\text { Ethanol plus many } \\
\text { fermentation } \\
\text { products }\end{array}$ & $\begin{array}{l}\text { Epidemiological studies } \\
\text { extensive. }\end{array}$ & $\begin{array}{l}\text { Major Abusive } \\
\text { intake associated } \\
\text { with mortality and } \\
\text { morbidity }\end{array}$ & $\begin{array}{l}\text { Moderate Range } \\
\text { of low intakes } \\
\text { almost certain to } \\
\text { decrease risk of } \\
\text { CHD. }\end{array}$ \\
\hline
\end{tabular}

Table 1: Classes of Food Constituents and Contaminants and Their Known and Potential Health Impacts.

\section{Drinking Water}

Water is important for hydration since lack of water can cause dehydration leading to death. Water is essential for preparation of food, sanitation and hygiene etc. The drinking water supply plays a major role of protecting human health as well as ensuring access to adequate quantities of safe water. Approximately $17 \%$ of the world's population uses water from the unprotected sources, $32 \%$ from protected sources and 51\% from centralized (piped) system. Water consumption occurs both at home, schools and workplaces. Drinking water is consumed by beverages and incorporated in foodstuffs. No one can survive without water. People need enough water to be healthy and water need to be safe. Water is not safe when germs and worms passed through the water. Chemicals from industry, mining and other waste can cause serious health problems that can affect humans. Diarrhea can be spread from one person to the other when there is shortage of water for personal hygiene. Contamination of water can make the effects of water scarcity worse making water unsafe and clean. Sources of drinking water are contaminated and required appropriate treatment to remove disease-causing contaminants. These sources may include naturally occurring chemicals and minerals. Local land use practice, industrial processes or wastewater releases.

Humans whose immune systems are compromised because of AIDS, chemotherapy or transplant medications may be vulnerable to these contaminants. Examples of water-borne diseases are Cholera, Bacillary dysentery, Infectious Hepatitis (jaundice), Poliomyelitis, Paratyphoid fever and Amoebic dysentery. Improper management of water resources can cause health hazards in humans and its environs. Water pipes should often be checked for leaks and cracks. To avoid free infection water should be boiled, filtered before usage. There is a need for risk assessment to ensure the disinfection of drinking water quality and preventing pathogenic organisms from being transmitted through the public water supplies. Filtration, chlorination, can be used to improve the establishment of drinking water quality $[2,3]$. 


\begin{tabular}{|l|l|l|l|}
\hline Disinfectants & $\begin{array}{l}\text { Oxidation Potential, at } \\
\mathbf{2 5 0 C}, \mathbf{~ V b}\end{array}$ & Relative Oxidation power & $\begin{array}{l}\text { Effectiveness as a } \\
\text { Disinfectant }\end{array}$ \\
\hline Hydroxyl radical & 2.80 & 2.05 & - \\
\hline Ozone & 2.07 & 1.52 & High \\
\hline Hydrogen peroxide & 1.77 & 1.30 & Moderate \\
\hline Hypochlorous acid & 1.49 & 1.10 & High \\
\hline Chlorine & 1.36 & 1.00 & High \\
\hline Hypobromous acid (bromine) & 1.33 & 0.98 & High \\
\hline Chlorine dioxide & 1.275 & 0.94 & High \\
\hline Monochloramine & 1,16 & 0.85 & Low \\
\hline Hypoiodous acid (iodine) & 0.99 & 0.73 & High \\
\hline
\end{tabular}

Source: From Rice and Gomez-Taylor (1986). Relative to the hydrogen electrode. Relative to chlorine $=1.0$

Table 2: Power of Alternative Drinking Water Disinfectants.

\section{Air Pollution related to Risk Assessment}

Air pollutants are the process where suspended particulate matter presents in outdoors air pose a threat to human health. The particulate matter (PM) concentrations have almost been expressed in terms of mass, although recent studies suggest that number concentration may correlate better with some effects than does mass [4, 5]. Humans are vulnerable to the effects of air pollution. Especially people who spend more time outdoors are more vulnerable to the effects of air pollutants. Air pollutants can harm the lungs of children causing them to have asthma since their lungs are still developing. To avoid health related problems associated with air pollutants, risk assessment agencies evaluated the statistical associations with health effects in most recent studies for which strong acid (H+) concentrations were measured.

Coherent responses for some health end points in human inhalation and in vitro studies at environmentally relevant doses. Much greater potency per unit mass in human inhalation studies shows larger diameter fine particle aerosols as well as induces lung inhalation. It was also found out that some particles are able to penetrate homes and buildings were people spend most of their time causing neonatal or post neonatal deaths. Poor air quality should be assessing on to improve the quality of the air. Air quality should be issued if there are a lot of dusts, exhaust, or smoke in the air. Avoidance of Toxic chemicals inn poorly ventilated areas [6-10].

As indicated in Table 3, fine and coarse particles generally have distinct sources and formation mechanisms, although there may be some overlap. 


\begin{tabular}{|c|c|c|}
\hline Components & Evidence for role in Effects & Doubts \\
\hline Strong acid $\left(\mathrm{H}^{+}\right)$ & $\begin{array}{l}\text { Statistical associations with health } \\
\text { effects in most recent studies for } \\
\text { which ambient } \mathrm{H}^{+} \text {concentrations } \\
\text { were measured. Coherent responses } \\
\text { for some health end points in human } \\
\text { and animal inhalation and in vitro } \\
\text { studies at environmentally relevant } \\
\text { doses. }\end{array}$ & $\begin{array}{l}\text { Similar PM associated effects } \\
\text { observed in locations with low } \\
\text { ambient } \mathrm{H}^{+} \text {levels. } \\
\text { Very limited data base on ambient } \\
\text { concentrations. }\end{array}$ \\
\hline Ultrafine particles $(\mathrm{D} \leq 0.2 \mathrm{um})$ & $\begin{array}{l}\text { Much greater potency per unit mass } \\
\text { in animal inhalation studies (H+, } \\
\text { Teflon, and } \mathrm{T}_{1} \mathrm{O}_{2} \text { aerosols) than same } \\
\text { materials in larger diameter fine } \\
\text { particle aerosols. Concept of } \\
\text { "irritating signaling" in terms of } \\
\text { number of particles per unit airway } \\
\text { surface. }\end{array}$ & $\begin{array}{l}\text { Absence of relevant data base on } \\
\text { ambient concentrations. }\end{array}$ \\
\hline Soluble transition metals & $\begin{array}{l}\text { Recent animal study evidence of } \\
\text { capability to induce lung } \\
\text { inflammation }\end{array}$ & $\begin{array}{l}\text { Absence of relevant data on } \\
\text { responses in humans. } \\
\text { Absence of relevant data on ambient } \\
\text { concentrations }\end{array}$ \\
\hline Peroxides & $\begin{array}{l}\text { Close association in ambient air with } \\
\mathrm{SO}_{4}=\text { Strong oxidizing properties }\end{array}$ & $\begin{array}{l}\text { Absence of relevant data on } \\
\text { response in humans or animals. } \\
\text { Very limited database on ambient } \\
\text { concentrations. }\end{array}$ \\
\hline
\end{tabular}

Table 3: Components of Ambient Air PM That May Account for Some or All of The Effects Associated with PM exposures.

\section{Conclusion}

Effective monitoring and exposure control strategies should be in place to achieve exposure results that do not result in adverse changes in health parameters. Health surveillance programs can provide insight on the effectiveness of control strategies in addition to their purposes. Environmental Engineers must understand the limits of existing technologies. The sciences of risk assessments can be used to measure and compare the benefits of possible options concerning the problem of understanding health-environmental risks. There should be a need to be more organized efforts to identifying the potential hazards that be uniquely associated with each disinfectants considered for broad 
application. It is essential to evaluate the effectiveness of public health outreach and involvement efforts associated with environmental risk, as they are being implemented and after the process is complete. This provides correction and improvement, both as the process advances in the future efforts.

\section{References}

1. Smith RL. Does one man's meat become another man's poison? Trans Med Soc Land 108 (1991): 6-17.

2. Bull RJ, Gerba C, Trussell RR. Evaluation of the health risks associated with disinfection. Crit Rev Environ Control 20 (1990): 77-133.

3. Blackburn BG, Craun GF, Yoder JS. Surveillance for waterborne disease outbreaks associated with drinking water, United States 2001-2002. MMWR Surveill Summ 53 (2004): 23-45.

4. Peters A, Wichmann E, Tuch T. Respiratory effects are associated with the number of ultrafine particles. Am J Respir Crit Care Med 155 (1997): 1376-1383.

5. Stolzel M, Peters A, Wichmann HE. Daily mortaility and fine and ultrafine particles in Erfurt, Germany. Revised Analyses of Time-Series Studies of Air Pollution and Health. Special report. Boston, MA: Health Effects Institute (2003): 231-240.

6. U.S. EPA. Review of the National Ambient Air Quality Standards for Particulate Matter: OAQPS Staff paper. EPA- 452/R-96-013. Research Triangle Park, NC: US. Environmental Protection Agency (1996).

7. U.S. EPA. Review of the National Ambient Air Quality Standards for Particulate Matter: OAQPS Staff paper. EPA- 452/R-96-013. Research Triangle Park, NC: US. Environmental Protection Agency (1996).

8. Woodruff TJ, Grillo J, Schoendorf KC. The relationship between selected causes of postneo-natal infant mortality and particulate air pollution in the United States. Environs Health Perspect 105 (1997): 608-612.

9. Bobak M, Leon DA. Pregnancy outcomes and outdoor air pollution: an ecological study in districts of Czech Republic 1986-1988. Environ Med 56 (1999): 539-543.

10. Maisonnet M, Bush TJ, Correa A. Relation between ambient air pollution and low birth weight in the northeastern United States. Environs. Health Perspect 109 (2001): 351-356.

11. Brock WJ, Rodricks JV, Rulis A, et al. Food safety and risk assessment. Int J Toxicol 22 (2003): 435-451.

12. Doull J. Food and safety and toxicology. Ed.: Roberts HR. Food safety. New York: John Wiley and sons (1981).

13. Kotsonis FN, Burdock GA, Flamm WG. Food Toxicology. Ed.: Klaassen CD. Casarett and Doull's toxicology (6th Edn). McGraw Hill, New York (2001).

14. NRC. Understanding Risk. Washington DC: National Academy Press (1996).

15. Reddy BS, Cohen LA. Diet, Nutrition and Cancer: A Critical Evaluation. Boca Raton, FL: CRC Press (1986).

16. Rice RG, Gomez-Taylor M. Ocurrence of by-products of strong oxidants reacting with drinking water contaminants-scope of problem. Environ Health Perspect 69 (1986): 31-44.

17. Ritz B, Yu F, Chapa G, et al. Effects of air pollution on preterm birth among children born in southern California between 1989 and 1993. Epidemiology 11 (2000): 502-511. 
Citation: Sylvia Adipah. Introduction of Human Health associated with Risk Assessment. Journal of Environmental Science and Public Health 2 (2018): 179-187.

(C) 1 This article is an open access article distributed under the terms and conditions of the
Creative Commons Attribution (CC-BY) license 4.0 